\title{
BLOOD VOLUME IN CLINICAL SHOCK.1,2 II. THE EXTENT AND CAUSE OF BLOOD VOLUME REDUCTION IN TRAUMATIC, HEMORRHAGIC, AND BURN SHOCK
}

\author{
By ROBERT P. NOBLE and MAGNUS I. GREGERSEN with THE TECHNICAL \\ ASSISTANCE OF PRISCILLA M. PORTER AND ANN BUCKMAN \\ (From the Department of Physiology of the College of Physicians and Surgeons, Columbia \\ University; the Department of Medicine of the College of Physicians and Surgeons, \\ Columbia University; the 3rd Surgical and the Tuberculosis Services of the \\ Bellevue Hospital, New York City)
}

(Received for publication September 8, 1945)

In their studies on wounded soldiers in World War I, Keith (1) and Robertson and Bock $(2,3)$ found evidence of a direct relation between the severity of shock and the extent of the reduction in blood volume. This has been clearly demonstrated in recent experimental studies on traumatic and hemorrhagic shock in dogs $(4,5)$ in which blood volume was determined with more dependable methods. Within the past two years, there have also been reports of similar observations on cases of shock among civilians $(6,7,8$, and others).

The aim of the present investigation was: (1) to determine more precisely the relation between the loss in blood volume and the severity of shock in man, in order to provide a sound basis for estimating the amount of blood needed for replacement after various types and degrees of injury; (2) to determine the cause of blood volume reduction in traumatic shock; and, (3) to test the view, held until recently by some investigators, that hemoconcentration is a criterion of shock.

\section{MATERIAL AND METHODS}

The plasma volume was measured with $\mathrm{T}-1824$ by extrapolation of a corrected time log-concentration curve as described in the preceding report (9); the total blood volume was calculated from the plasma volume and the arterial hematocrit. The serum protein concentration was determined by the falling drop (10) and refractometric

1 This investigation was carried out at Bellevue Hospital under a contract, recommended by the Committee on Medical Research, between the Office of Scientific Research and Development and Columbia University with the collaboration of New York University.

2 Generous support for these studies of blood volume in shock was provided also by the Josiah Macy, Jr. Foundation.
(11) techniques. The preceding report gives complete details (9).

The clinical material included a group of 51 normal students and laboratory workers and 109 patients admitted to the emergency service at Bellevue Hospital, New York City. Of the various types of cases studied 38 were predominantly traumatic, 24 were cases of hemorrhage, 21 were burns, and the remainder suffered from various other injuries, as shown in Table $I$ in the preceding report (9). Varying degrees of shock were encountered. Additional information regarding the criteria used in evaluating the degree of shock, the general procedures followed, and other results have been reported by Cournand et al. $(8,12)$, by Lauson et al. (13), and by Richards (14).

\section{RESULTS}

The attempt to establish a correlation between blood volume reduction and shock in human cases is complicated by the fact that control determinations of plasma and blood volumes before injury are not available. Hence, for the estimate of the loss in volume one must rely on a comparison of the measured volume with an average normal value. The average values determined by various investigators agree moderately well (15 to 20). However, in using the average normal value one must not overlook the fact that the range is wide and that the normal blood volume may occasionally deviate considerably from the assumed average value.

From the distribution curves in Figure 1 it may be seen that the plasma volumes in 51 normal male subjects (20) ranged from 34 to $58 \mathrm{ml}$. per $\mathrm{kgm}$. body weight. Expressed in terms of $\mathrm{ml}$. per sq.M., the range was from 1200 to $2200 \mathrm{ml}$. The average plasma volume for the group was $44.7 \mathrm{ml}$. per $\mathrm{kgm}$. body weight with a standard deviation of $4.9 \mathrm{ml}$. per kgm., or $1670 \mathrm{ml}$. per sq.M. of body surface area with a standard deviation of 161 $\mathrm{ml} /$ per sq.M. 
20

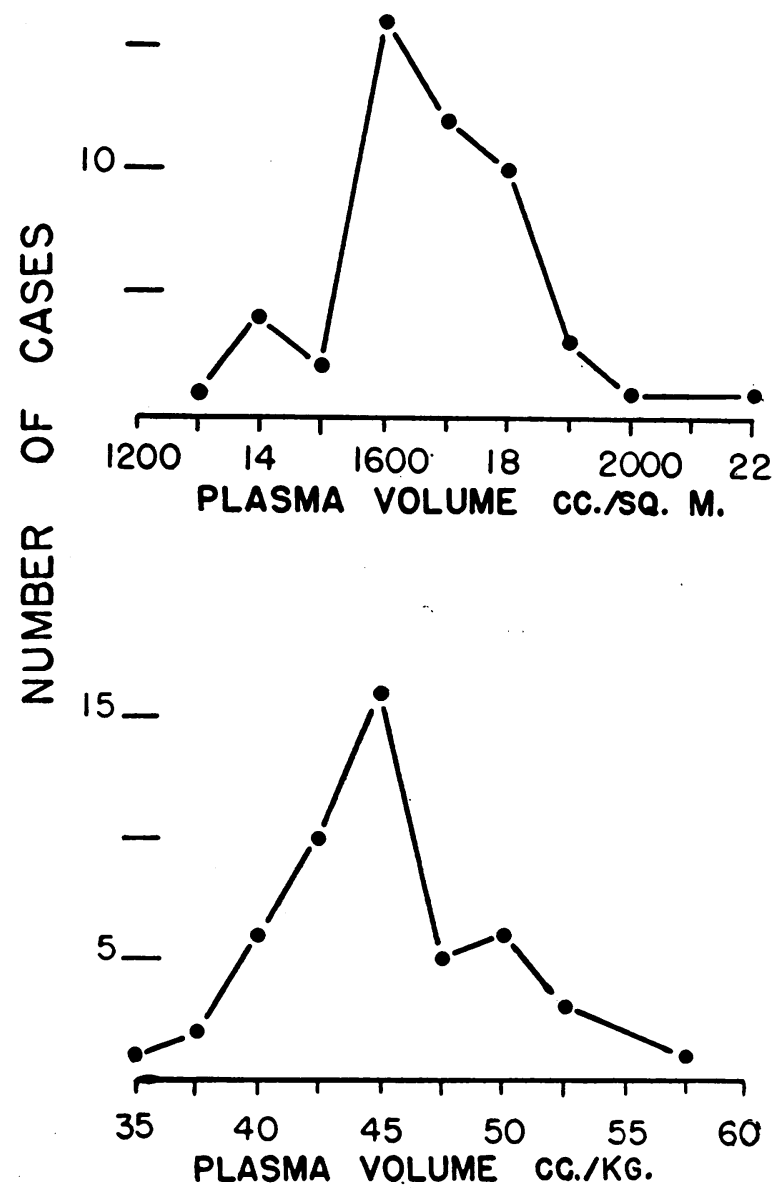

Fig. 1. The Range and Distribution of Plasma Volumes (20) in 51 Normal Male Subjects (plotted AS ML. PER SQ.M. OF BODY SURFACE AREA, AND AS ML. PER KGM. OF BODY WEIGHT)

The average normal plasma volume, derived from these results was found to be $1670 \mathrm{ml}$. per sq. M. (S.D. 161 ml.) or $44.7 \mathrm{ml}$. per kgm. (S.D. $4.9 \mathrm{ml}$.).

In 37 determinations on 18 subjects the total blood volume ranged from 65 to $100 \mathrm{ml}$. per $\mathrm{kgm}$. or 2400 to $3700 \mathrm{ml}$. per sq.M. The average of these is $85.1 \mathrm{ml}$. per kgm. (S.D. $8.9 \mathrm{ml}$ per kgm.) or $3200 \mathrm{ml}$. per sqM. (S.D. $315 \mathrm{ml}$. per sq.M.). The results are summarized in Table I for comparison with the average normal values taken from the literature. It is apparent from these observations that the majority of blood volumes on normal subjects will fall within 8 to 10 per cent of the average value. As will be seen below, the reductions in plasma and blood volume in shock are so large in comparison with the normal variations that the error in estimating the amount of blood or plasma needed by the patient will seldom be serious. In the present study the reduction was apparently underestimated in only two cases. In both instances the estimate was still sufficiently accurate for purposes of determining the amount of transfusion needed to bring the patients out of danger.
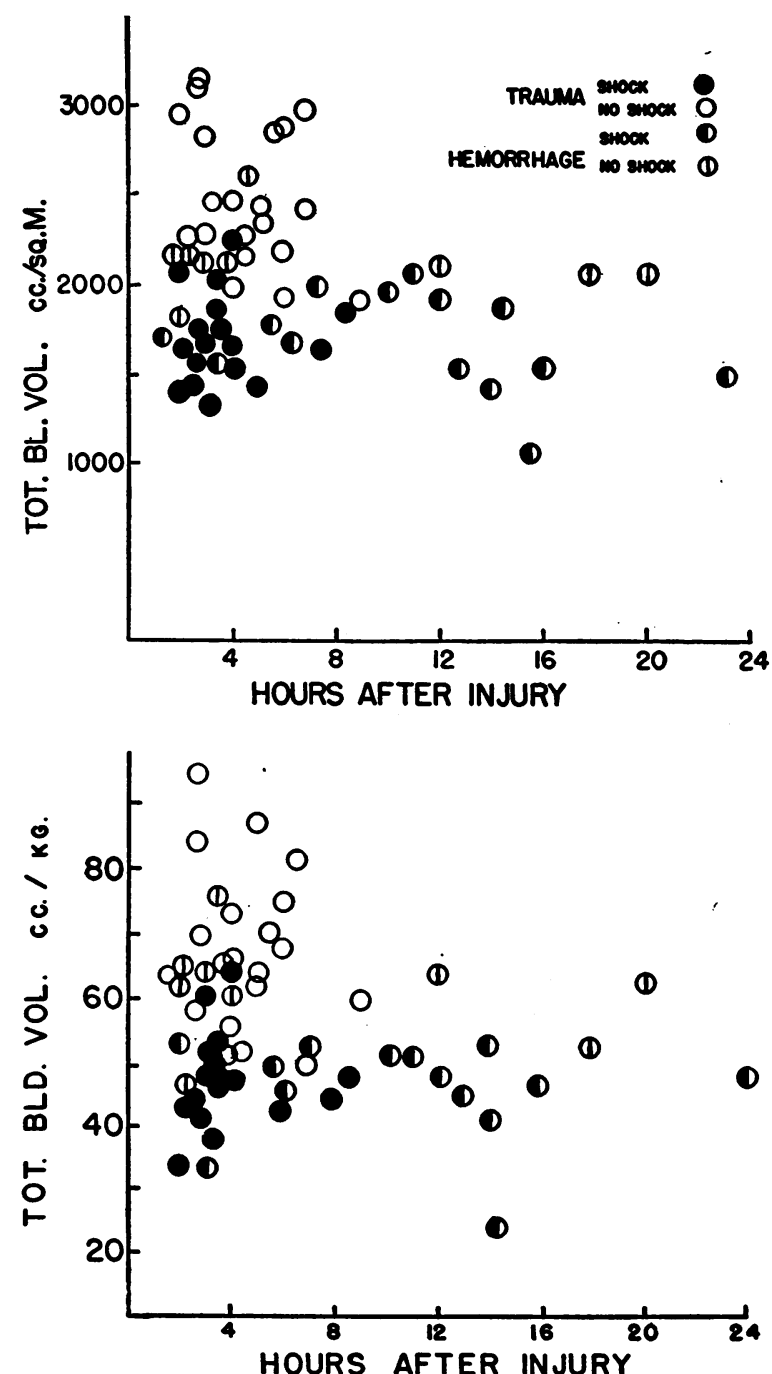

Fig. 2. Blood Volume Determinations on Patients with either Skeletal Trauma or Hemorrhage

The observations were made at the time of admission and before any treatment had been given. It will be noted that in nearly all the patients who were in shock (designated by solid and half solid circles) the blood volume was at or below $2000 \mathrm{ml}$. per sq. M. or $55 \mathrm{ml}$. per kgm. This represents a reduction of approximately 35 per cent from the average normal value. 
TABLE I

Average plasma volume and total blood volume in normal men

\begin{tabular}{|c|c|c|c|c|c|c|c|c|}
\hline \multirow{2}{*}{ Author } & \multirow{2}{*}{ Dye } & \multirow{2}{*}{$\begin{array}{l}\text { No. of } \\
\text { cases }\end{array}$} & \multirow{2}{*}{$\begin{array}{l}\text { Age aver. } \\
\text { (range) }\end{array}$} & \multicolumn{2}{|c|}{ Plasma volume } & \multirow{2}{*}{$\underset{\text { crit }}{\text { Hemato- }}$} & \multicolumn{2}{|c|}{ Total blood vol. } \\
\hline & & & & $\underset{\text { ml. per }}{\text { mgm. }}$ & $\begin{array}{l}\text { ml. per } \\
\text { sq.M. }\end{array}$ & & $\begin{array}{l}\text { ml. per } \\
\text { kgm. }\end{array}$ & $\begin{array}{l}\text { ml. per } \\
\text { sq.M. }\end{array}$ \\
\hline $\begin{array}{l}\text { Keith, Rowntree and Geraghty } \\
\text { (15) }-1915\end{array}$ & $\begin{array}{l}\text { brilliant } \\
\text { vital red }\end{array}$ & 42 & $\begin{array}{l}32.6 \\
(20 \text { to } 53)\end{array}$ & 49.0 & 1764 & $42.4^{*}$ & $85.8^{*}$ & \\
\hline Rowntree and Brown (16)-1929 & congo red & 49 & $\begin{array}{l}33.7 \\
(17 \text { to } 62)\end{array}$ & 51.0 & 1938 & 42.0 & 88.6 & 3365 \\
\hline Gibson and Evans (17)-1937 & $\mathrm{T}-1824$ & 49 & $\begin{array}{c}35.5 \\
(19 \text { to } 89)\end{array}$ & 43.8 & 1624 & 44.7 & 77.7 & 2908 \\
\hline Stewart and Rourke $(18)-1941$ & $\mathrm{~T}-1824$ & 12 & $\begin{array}{c}34.0 \\
(16 \text { to } 62)\end{array}$ & 45.5 & 1680 & 45.0 & 85.3 & 3150 \\
\hline Davis (19)-1942 & $\mathrm{T}-1824$ & 11 & $\begin{array}{c}40.0 \\
(17 \text { to } 68)\end{array}$ & 40.5 & 1538 & 47.2 & 76.7 & 2897 \\
\hline Gregersen (20) & $\mathrm{T}-1824$ & 51 & $\begin{array}{l}23.6 \\
(21 \text { to } 37)\end{array}$ & 44.7 & 1670 & 45.0 & $85.1 \dagger$ & 3200 \\
\hline
\end{tabular}

* 18 cases.

BLOOD VOLUME IN SHOCK

The blood volumes determined at the time of admission on patients with hemorrhage or skeletal trauma are shown in Figure 2. In chart A the results are plotted in ml. per sq.M., and in chart $\mathrm{B}$ they are shown in $\mathrm{ml}$. per $\mathrm{kgm}$. The solid circles (trauma) and the half-solid circles (hemorrhage) denote patients who, on the basis of clinical findings and from the laboratory data accumulated later, were classified as cases of severe shock. With few exceptions the total blood volume in these patients fell at or below $2000 \mathrm{ml}$. per sq.M. or $55 \mathrm{ml}$. per kgm. Compared with the average normal value, this represents a reduction of about 35 to 40 per cent. One may conclude from these observations that a patient in severe shock from either hemorrhage or trauma has lost approximately 2 liters of blood. The cases showing only mild or moderate degrees of shock have been grouped here with the "no shock" cases. The blood volumes in these borderline cases ranged from 2000 to $2500 \mathrm{ml}$. per sq.M.-a reduction of 20 to 30 per cent (see Figure 6).

A factor to be considered in evaluating the determinations of total blood volume is the distribution of the erythrocytes in the circulation. Several investigators have reported unequal distribution of red cells in man and in normal animals and have concluded that blood drawn from large ves- sels gives hematocrit values approximately 25 per cent higher than the average body hematocrit (21 to 26). However, in order to account for a discrepancy of this magnitude, the volume of blood contained in the capillaries would have to be much greater than the estimates derived from anatomical data and from the relation between linear velocity and total cross section area in different parts of the vascular bed. Bazett (27) concluded that the capillaries and venules together contain only 13 per cent of all the blood. Furthermore, the results of recent studies on humans and on dogs (28 to 31), especially those of Root, Roughton, and Gregersen (32), in which the blood volume was determined simultaneously with the dye method (T-1824) and with an improved carbon monoxide method, show little difference between the central arterial hematocrit and the body hematocrit. In other words, these tests indicate that the total blood volume measured by the dye method agrees satisfactorily with the true total blood volume (total plasma volume determined with dye plus total red cell volume determined with carbon monoxide).

Further evidence that the determinations of total blood volume in shock are essentially correct is obtained from a comparison between the volume of red cells given by transfusion and the observed increase in circulating red cell volume. The five 
cases shown in Table II were patients who were in shock from hemorrhage at the time the first volume measurements were made. In three instances a measured amount of red cells and plasma proteins was given by transfusion. The patients recovered rapidly from circulatory failure, and the determinations were then repeated. It will be seen from Table II that the measured increases (R.B.C. recovered) in the total erythrocyte volume and the total circulating proteins agree well with the quantity of cells and proteins given.

The last two patients listed in Table II were treated with concentrated human serum albumin, prepared from pooled normal human plasma by Cohn and co-workers (33). This caused a large drop in the hematocrit value. Although these patients were known to have had no further blood loss, the measurements indicate a reduction, in one case 4 per cent in the other 8 per cent, of the red cells in circulation. This finding appears similar to observations on hemorrhage reported by Stead and Ebert (25) and by others (34 to 36).

A. The cause of the blood volume reduction in trauma. The observed reduction in the blood volume is readily explained in cases of hemorrhage, but in skeletal trauma there may be little evidence of gross external bleeding. Nevertheless, various lines of evidence indicate that the decrease in blood volume in skeletal trauma is caused by bleeding and by extensive hematomas that are usually found about the fractures. The total amount of blood lost in the formation of these will, in general, depend upon the extent of muscle contusion, upon the number of fractures, and upon their relation to blood vessels. This is brought out in Figure 3 in which the first three columns show the relation between the blood volume on admission and the number of fractures of the extremities irrespective of the type (i.e. simple, comminuted, or compounded). Three or more such fractures are evidently sufficient to reduce the blood volume to shock level, whereas a comparable reduction in volume is often brought about by fracture of the pelvis alone. The greatest volume reduction was found in patients suffering fractures of the pelvis together with fractures of the extremities. ${ }^{3}$

In cases where enlargement of a hematoma was noted, a second determination of the blood volume invariably revealed a further loss of whole blood. This is to be seen in Table III which gives the measured volumes of plasma, red cells, and total protein on two successive determinations. In each instance the volume of the constituent lost from the circulation was obtained as the difference between the first and second measured volumes. This includes the volume of blood removed as samples. The first six observations are on patients in whom the hemorrhage continued between successive determinations. The first two patients were bleeding from peptic ulcers. Between the

3 The quantity of blood required for replacement in patients of average size is shown by the scale on the right in Figure 3. The unit of body surface area, 1.73 sq.M., is the average of the areas of adult men and women (37). The average size of the patients on whom the present studies were obtained was 1.72 sq.M. or $61.9 \mathrm{kgm}$. of body weight. As may be seen in Figure 2, if the calculations for the volume of transfusion were made on the basis of body weight, there would be little difference in these values. In larger patients correspondingly larger transfusions should be given, although in this study transfusions smaller than the amounts indicated were usually sufficient to promote recovery from shock.

TABLE II

\begin{tabular}{|c|c|c|c|c|c|c|c|c|c|c|c|c|c|c|}
\hline \multirow{2}{*}{ Patient } & \multirow{2}{*}{\multicolumn{2}{|c|}{$\underset{\text { interval }}{\text { Time }}$}} & \multicolumn{4}{|c|}{ Total plasma volume } & \multicolumn{4}{|c|}{ Total erythrocyte volume } & \multicolumn{4}{|c|}{ Total circulating protein } \\
\hline & & & $\begin{array}{l}\text { First } \\
\text { deter- } \\
\text { mined }\end{array}$ & $\begin{array}{l}\text { Second } \\
\text { deter- } \\
\text { mined }\end{array}$ & $\begin{array}{c}\text { Plasma } \\
\text { given } \\
*\end{array}$ & $\begin{array}{c}\text { Plasma } \\
\text { recov- } \\
\text { ered }\end{array}$ & $\begin{array}{l}\text { First } \\
\text { deter- } \\
\text { mined }\end{array}$ & $\begin{array}{l}\text { Second } \\
\text { deter- } \\
\text { mined }\end{array}$ & $\underset{*}{\text { R.B.C. }} \underset{\text { given }}{\text {. }}$ & $\begin{array}{l}\text { R.B.C. } \\
\text { recov- } \\
\text { ered }\end{array}$ & $\begin{array}{l}\text { First } \\
\text { deter- } \\
\text { mined }\end{array}$ & $\begin{array}{l}\text { Second } \\
\text { deter- } \\
\text { mined }\end{array}$ & $\begin{array}{c}\text { Protein } \\
\text { given } \\
*\end{array}$ & $\begin{array}{l}\text { Protein } \\
\text { recov- } \\
\text { ered }\end{array}$ \\
\hline $\begin{array}{l}\text { A. H. } \\
\text { A. S. } \\
\text { M. B. } \\
\text { F. C. } \\
\text { B. S. }\end{array}$ & $\begin{array}{c}\text { hrs. } \\
3 \\
4 \\
2 \\
3 \\
4\end{array}$ & $\begin{array}{c}\min . \\
30 \\
30 \\
00 \\
45 \\
40\end{array}$ & $\begin{array}{c}m l . \\
1950 \\
1079 \\
2200 \\
1960 \\
2160\end{array}$ & $\begin{array}{c}m l . \\
2290 \\
2450 \\
2660 \\
3000 \\
3110\end{array}$ & $\begin{array}{c}m l . \\
440 \\
390 \\
200 \\
\text { conc. a } \\
\text { conc. a } \\
+75 \mathrm{ml}\end{array}$ & $\begin{array}{c}\text { ml. } \\
340 \\
660 \\
460 \\
\text { bumin } \\
\text { pumin } \\
\text { plasma }\end{array}$ & $\begin{array}{r}m l . \\
490 \\
480 \\
1680 \\
1100 \\
1320\end{array}$ & $\begin{array}{c}m l . \\
850 \\
890 \\
1810 \\
1060 \\
1270\end{array}$ & $\begin{array}{r}m l . \\
375 \\
380 \\
100 \\
0 \\
50\end{array}$ & $\begin{array}{r}m l . \\
350 \\
410 \\
130 \\
-40 \\
-100\end{array}$ & $\begin{array}{c}\text { grams } \\
82 \\
85 \\
128 \\
100 \\
147\end{array}$ & $\begin{array}{c}\text { grams } \\
108 \\
115 \\
141 \\
162 \\
190\end{array}$ & $\begin{array}{c}\text { grams } \\
26 \\
26 \\
12 \\
70 \\
47\end{array}$ & $\begin{array}{c}\text { grams } \\
30 \\
30 \\
13 \\
62 \\
43\end{array}$ \\
\hline
\end{tabular}

* The values for the various constituents given or recovered have been corrected for the volume of that constituent removed as samples. 


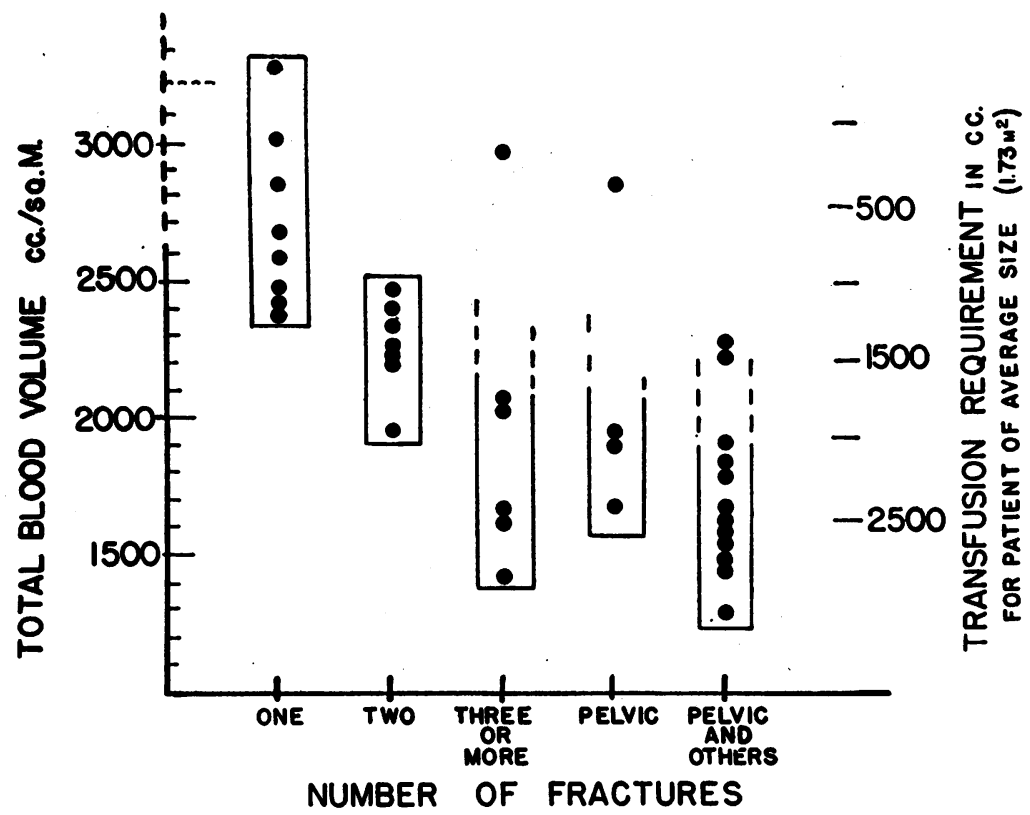

Fig. 3. Showing the Total Blood Volume on Admission in Relation to the Number of Fracture Sites Irrespective of the Type of Fracture

One may conclude that the blood lost at the site of three or more fractures or from a fracture of the pelvis is usually sufficient to reduce the blood volume to shock level (2000 ml. per sq. M. or below).

The dotted portion of the scale on the left represents twice the standard deviation from the average normal blood volume. The scale on the right indicates the quantity of blood or plasma required for transfusion in patients of average size.

time of the second and third measurements on the third patient, W. K., it was noted that the bandage over a large gash in the forearm was soaked with blood, some of which had dripped on the floor. The fourth patient, T. L., suffered a ruptured spleen and at operation was found to have several liters of bloody fluid in the peritoneal cavity. In this instance it can be seen from the erythrocyte volume measurements (column A) that $460 \mathrm{ml}$. of red cells were lost in the first four hours after admission. Since hemorrhage involved the escape of whole blood, red cells were accompanied by a proportional complement of plasma proteins. The volume of plasma lost in hemorrhage can be estimated from the average hematocrit value existing during the bleeding period. The decrease in the amount of total circulating protein is then obtained from the prevailing plasma protein level. In the patient just mentioned the amount of plasma lost was calculated at $1020 \mathrm{ml}$. Since the protein concentration was 5.9 grams per $100 \mathrm{ml}$., 60 grams of plasma proteins were lost (column
B). During the same time the total measured decrease in total circulating protein was 63 grams (column C). During the next $31 / 2$ hours the patient received a transfusion of whole blood, and the third blood volume determination showed that he had bled an additional $210 \mathrm{ml}$. of cells (column A). The observed decrease in total circulating protein was 37 grams (column C). Column B shows that the derived value for the protein loss was 33 grams. In these cases the values for protein lost, measured directly and calculated indirectly, warrant the conclusion that further hemorrhage occurred between determinations. In each instance this conclusion was borne out by the clinical observation of the hemorrhage.

When this same analysis is applied to the cases of skeletal trauma, it becomes apparent that the reduction in the blood volume in trauma is also caused by whole blood loss. For example, the last four patients listed under trauma in Table III suffered multiple fractures and contusions, except for J. S. who received an extensive crush- 
TABLE II*

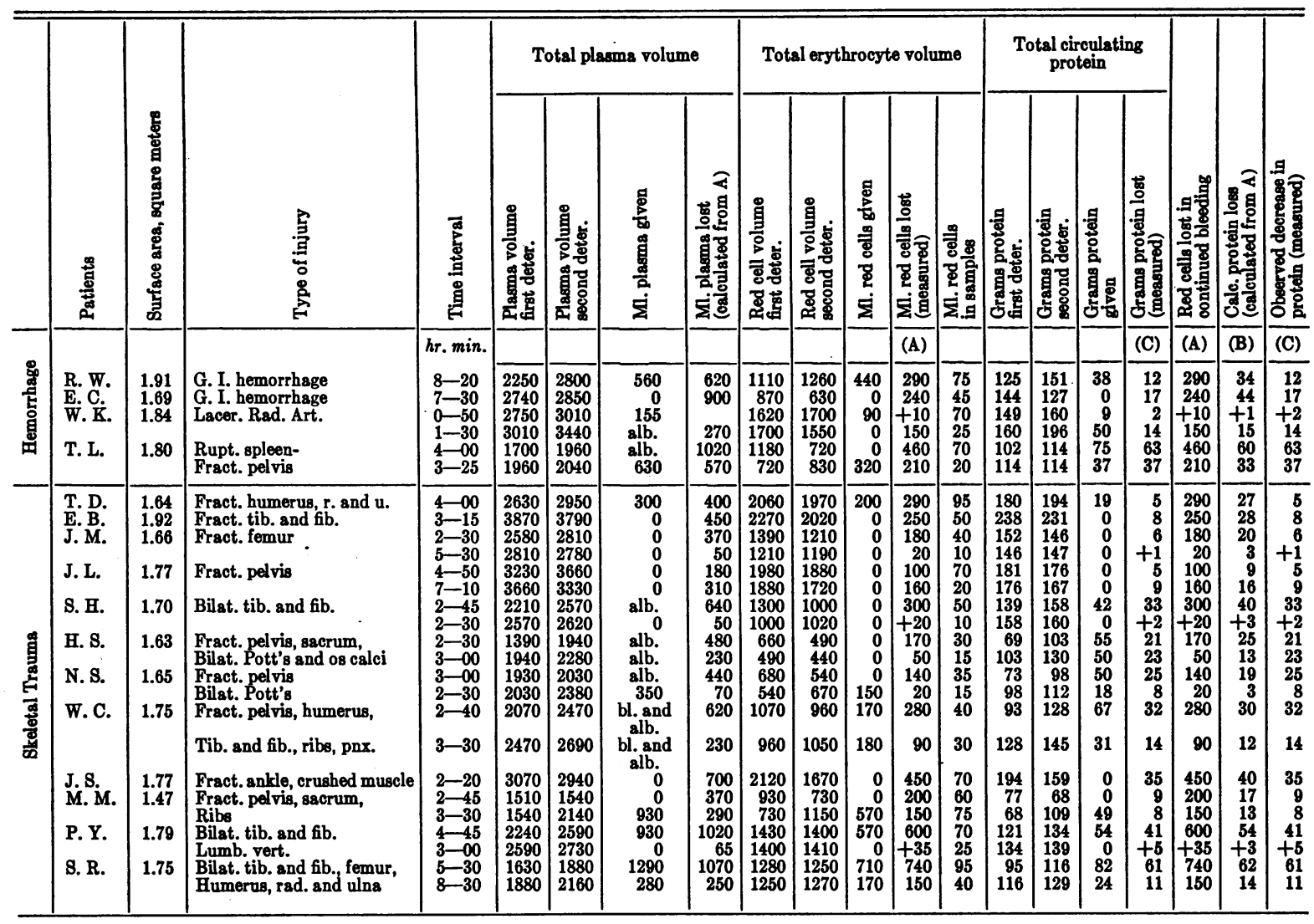

* In the above calculations the effect of changes in hematocrit on successive measurement of the red cell volume tends to exaggerate the loss of red cells and therefore gives unduly large calculated values for loss of plasma volume and plasma protein. Other errors include the estimates of the volume of blood transfused and the volume of samples removed from the inlying arterial needle. The fragility of the red cells may also be involved. In view of these several errors only the trend is considered significant. No effort has been made to elucidate upon the relation of shock to protein and fluid replacement, the rate of hemodilution, etc.

ing injury and fracture of one leg. In each of these cases progressively enlarging hematomas were observed at the fracture sites. S. Ru. was the most striking example; he received one or more fractures in each extremity and fractures of the pelvis, having fallen three stories down an elevator shaft. Massive hematomas were observed to be increasing in size along one flank and about a badly comminuted fracture of the mid-humerus with the hematoma extending up into the shoulder and pectoral regions. The protein and red cell values in Table III show that of the two liters of blood transfused more than one-half was lost, presumably into the enlarging hematomas. In each of the other cases protein and red cells were lost in such proportions as to be best explained by the loss of whole blood, and this loss was observed to coincide with the formation or enlargement of hematomas. This indicates that the progressive reduction in the blood volume after a skeletal trauma may be accounted for by the loss of whole blood into the soft tissues in the region of injury.

This conclusion is further substantiated if the reduction in the blood volume in cases of hemorrhage and trauma is expressed in terms of the reduction of the total plasma proteins and erythrocyte volume. For, if the reduction in blood volume is caused by hemorrhage in both types of injury, there should be a proportionate reduction in both total circulating protein and total erythrocyte volumes at the time of the patient's admission. That this is correct is shown in Figure 4 in .which the total circulating protein in grams per sq. $M$. is plotted against the total red cell volume in $\mathrm{ml}$. per sq. M. The values for total protein and red cells in cases of both hemorrhage and trauma show the 
same trend along the diagonal, the diagonal indicating a proportional loss of both plasma and erythrocytes.

The cause of blood volume reduction in burns is generally acknowledged to be plasma leakage in the region of injury. The data in Figure 5 are in accord with the generally accepted facts that the amount of plasma exudation depends in part upon the area of body surface burned. It has been noted that second degree burns involving a larger portion of the body surface area show a greater reduction in plasma volume and higher

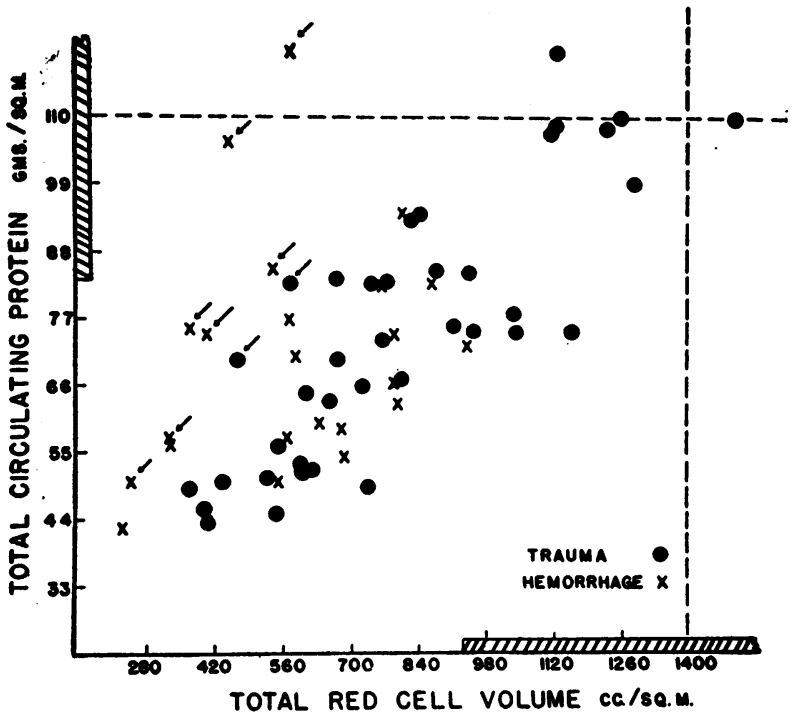

Fig. 4. Showing the Relation Between the Total Circulating Plasma Proteins and the Total Red Cell Volume in Patients with Trauma and Hemorrhage as Measured at the Time of Admission

The total circulating plasma proteins are plotted on the ordinate as grams per sq. M. and the total red cell volume along the abscissa as $\mathrm{ml}$. per sq. M. The scale divisions from the average normal values (dotted lines) represent equal reduction in both constituents. The approximate range of average normal values are indicated by the striped columns on the vertical and on the horizontal axis. Patients assumed to have been anemic prior to admission, of which there were nine, are indicated by arrows (see Figure 6).

It will be seen that in cases of trauma and hemorrhage alike, there was a proportional reduction in protein and red cells. Since the blood volume reduction in hemorrhage is caused by the loss of whole blood and since the data in cases of trauma appear indistinguishable from those of hemorrhage, it becomes apparent that the cause for the reduction in blood volume in cases of traumatic shock is bleeding into the tissues at the site of injury (Figure 3).

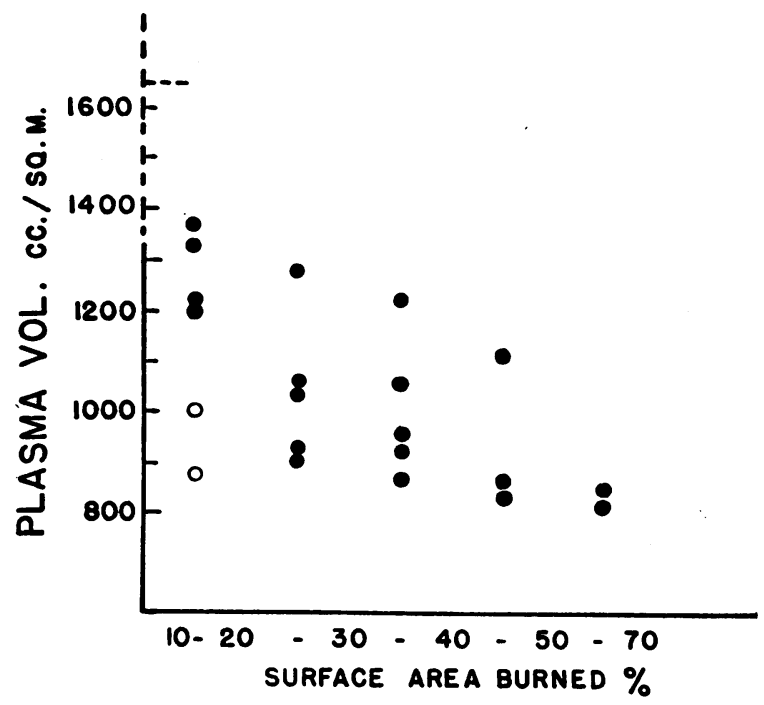

Fig. 5. Showing That the Reduction in Plasma Volume Observed in Burn Cases at the Time of Admission is Roughly Proportional to the Fraction of the Body Surface Burned

Two patients with burns predominantly of the head and neck are shown by open circles.

hematocrit values (38). Burns of the head and neck are recognized as resulting in the loss of plasma out of proportion to the area involved. Two patients in the series, burned in this region predominantly, confirm this observation. This should not be taken as evidence that plasma is lost from generalized capillary leakage remote from the area of injury, as recent investigators ( 39 to 41 ) have demonstrated that, in burn shock, plasma and fluid loss occur solely in the region of the burn.

\section{HEMOCONCENTRATION AS A CRITERION OF SHOCK}

The emphasis in recent years upon hemoconcentration as a criterion of shock $(42,43)$ led us to examine the relations between serum protein concentration, hematocrit values, and the blood volume reduction in the various types of injuries presented by these patients. The results are shown in Figure 6. In each case, the columns representing the blood volumes are divided into the plasma and red cell (stippled) compartments. Under the columns representing blood volumes are noted the value for cardiac output (Fick method) expressed as liters per square meter of body surface (cardiac index), and the systolic and 


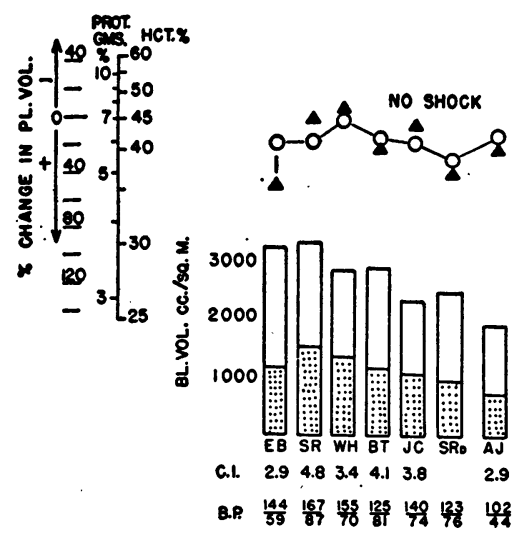

SKELETAL TRAUMA

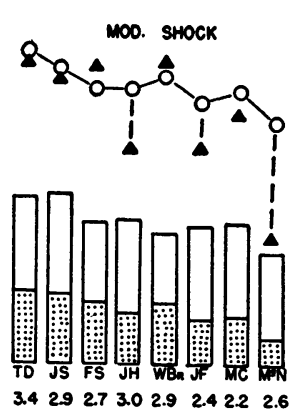

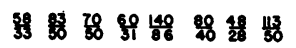
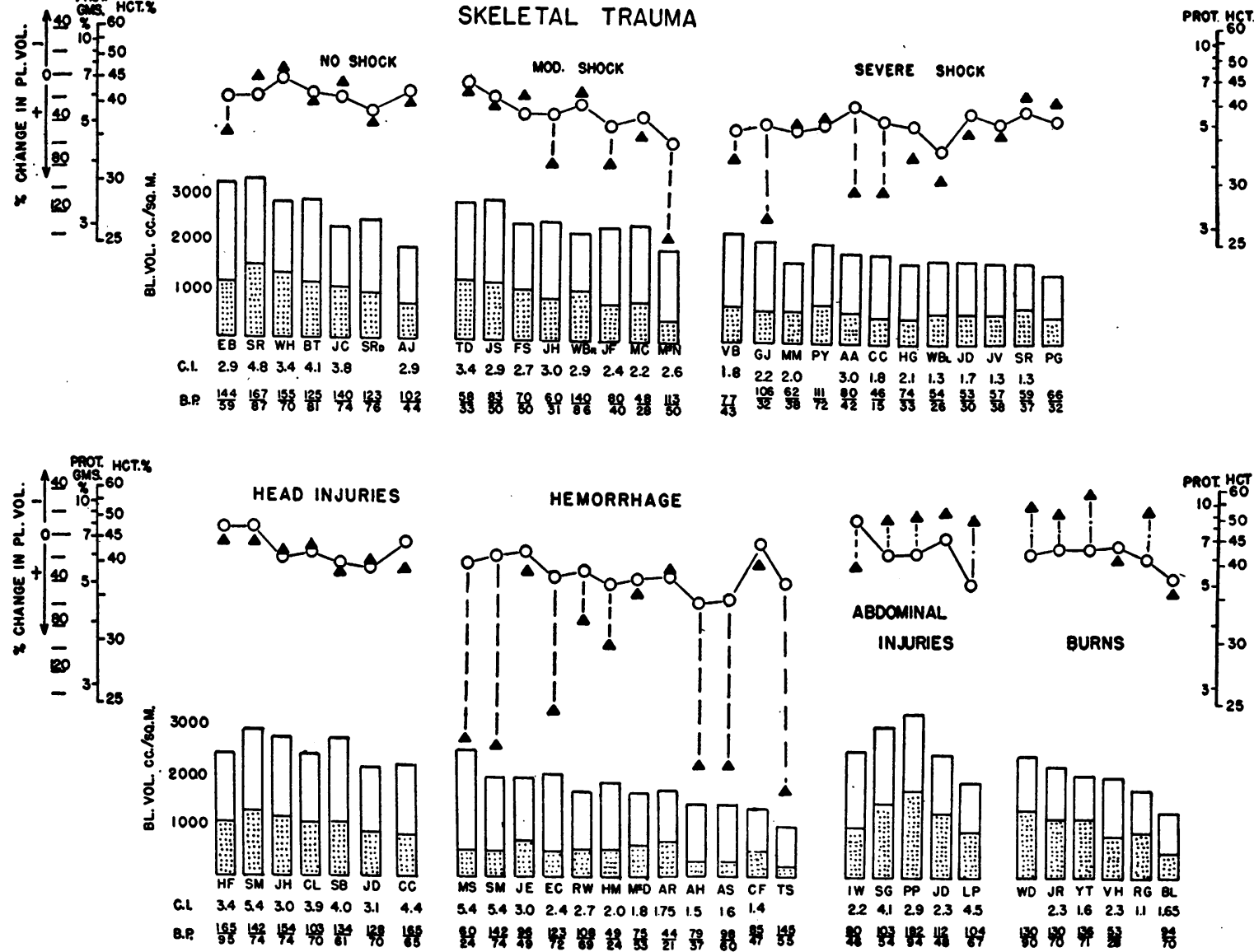

Fig. 6. Showing the Serum Protein (open circles) and Hematocrit Readings (solid triangles), Cardiac Output, Blood Pressure and Blood Volume Values on Patients at Time of Admission

The stippled portion of the blood volume columns represents the red cell volume, and the open portion, the plasma volume. It is clear that there was no hemoconcentration in skeletal trauma and hemorrhage. On the contrary, the blood volume reduction was accompanied by hemodilution. Only cases of abdominal injury with peritonitis and cases of burns showed a selective plasma leakage and hemoconcentration. Note the relationship of the reduction in blood volume and cardiac output to the depth of shock.

Patients showing disproportionately low hematocrit values on admission were considered to have been anemic prior to injury.

diastolic blood pressure in $\mathrm{mm}$. $\mathrm{Hg}$ (Hamilton manometer). Approximately normal values for the various items on the chart are shown by patients with skeletal trauma ("no shock") and those with head injuries. The patients suffering from trauma and hemorrhage have been arranged more or less in the order of decreasing values for blood volume. In the hemorrhage group, the first two patients were not considered to be in shock. The next patients (N. C., R. W., and J. E.) were in moderate shock, but not as severe as those remaining. The chart points out the correlation between the blood volume reduction and shock and shows that with the reduction in blood volume there is a parallel decline in cardiac output (13). On the other hand, it is apparent that the isolated measurement of the blood pressure is not a good index of the degree of shock in the borderline cases.

The manner of plotting the hematocrit and plasma protein values requires some explanation. It will be noted first that the abscissae representing 7 grams per cent plasma protein and a hematocrit value of 45 per cent cells coincide. These are taken as average normal values. With this as a starting point, the scales for hematocrit and plasma protein have been so constructed that any given 
change in the plasma volume (indicated by the scale to the left) resulting from gain or loss of protein-free fluid will, on the chart, displace both the hematocrit and protein to the same extent. If the two values do not fall together on the chart, this will be evidence of a change in the ratio of total circulating protein to total red cell volume. In other words, divergence of the points will reveal whether the patient in question has lost more of one constituent than the other, either following injury or at some time prior to the injury. In patients with a chronic secondary anemia, the anemia is revealed by the disproportionately low hematocrit value. The prevalence of such patients among the hemorrhage cases is demonstrated. Each gave a history of previous bleeding. On the other hand, selective protein leakage is demonstrated on the chart by the relatively low plasma protein values among the patients with burns or with abdominal injuries. In these instances, elevated hematocrit values are found as the result of plasma leakage from the locally damaged tissue. When, however, a burn or abdominal injury with peritonitis is superimposed on anemia, there may be no evidence of hemoconcentration although the blood volume is markedly below normal. This point is well demonstrated by $\mathrm{V} . \mathrm{H}$. and the severely burned patient, B. L., who at no time prior to transfusion showed any evidence of hemoconcentration. The latter required more than two liters for replacement.

It is evident that hemoconcentration is by no means a regular occurrence in the patients in shock from trauma. Indeed, the normal compensatory mechanism of hemodilution apparently operates after trauma as well as after a simple hemorrhage, for both types of injury cause a similar degree of hemodilution.

\section{DISCUSSION}

It will be seen that the magnitude of the reduction in blood volume in shock found in the present study (Figure 2) is in essential agreement with the conclusions reached by Keith (1), and by Robertson and Bock $(2,3)$ in their pioneer studies on wounded soldiers in World War I. The original dye method (Keith-Rowntree) which they used for determining blood volume did not, to be sure, exclude certain possibilities of technical errors which have been eliminated in the present technique. Nevertheless, the systematic investigation of disappearance rate and mixing in shock cases (9) demonstrates that at least the fundamental principle was valid. Hence, on the basis of what is now known about the dye method and about the state of the circulation in shock, it is clear that the results obtained by these earlier investigators were essentially correct. What has been accomplished in the meantime is to clear up the misconception that shock is fundamentally a disturbance in capillary permeability and to show that the changes in volume and composition of the blood in shock can be accounted for without recourse to the theory of generalized capillary leakage.

Among the cases included in the present investigation, either hemorrhage or the local exudation of plasma in the injured region were the major causes of blood volume reduction. Only in a few cases did both mechanisms operate simultaneously.

Hemorrhage was observed in two types of injury. In the first group, the hemorrhage was obvious as in the cases of intestinal bleeding or in laceration of superficial vessels. In about onehalf of these, shock was caused by gastro-intestinal bleeding; a considerable number had chronic anemia from previous hemorrhages. In the remainder, acute blood loss was caused by self-inflicted wounds.

The second group was made up of cases of skeletal trauma, in which the fracture site, the relation of the movable fragments to blood vessels and muscle contusion appeared to be the major causes of blood loss. The type of skeletal trauma encountered varied from simple fracture with little bruising, to multiple fractures with large areas of muscle contusion. In a few cases, trauma was complicated by hemorrhage from ruptured abdominal viscera or chest injuries. Bullet wounds and uncomplicated muscle crushing were rarely seen. There were no cases comparable to the crush or tourniquet type of injury, and no cases of the "crush syndrome." The proportional loss of plasma proteins and erythrocytes indicates that in these cases, hemorrhage into the tissue spaces in the region of injury was responsible for the loss of whole blood, the external sign of which was the localized formation of progressively enlarging hematomas (Figures 3 and 4; Table III). 
These hematomas often escape notice, for it is not generally appreciated that the accumulation of one liter of blood in the thigh results in an increase of only one centimeter in the diameter of the region. ${ }^{4}$

The second major cause of blood volume reduction was the localized escape of plasma into the region of injury, seen in cases of burns and peritonitis. In burns there is weeping of plasma from the denuded areas and leakage of plasma into the tissues locally, giving rise in part to the tense edematous swelling underlying and surrounding the burned region. In the majority of the burns in this series, the area involved was between 20 and 40 per cent of the body surface area. Burns were occasionally associated with pulmonary complications. Gross intravascular hemolysis and hematuria appeared in a few cases.

The patients with abdominal injuries suffered from peritonitis either as the result of rupture of hollow organs or from the presence of blood in the peritoneal cavity. The nature of the destructive injury causes the selective loss of plasma into the peritoneal cavity which, in the absence of anemia, results in hemoconcentration (Figure 6). Owing to the loss of plasma proteins, the value for protein concentration is low and therefore distinguishes this condition from dehydration.

Hemodilution is a normal compensatory mechanism following blood loss. It is apparent from the results presented in Figure 6 that hemodilution followed blood volume reduction whether the blood loss was occasioned by uncomplicated hemorrhage or by trauma. In both types of injury the serum protein and hematocrit values before treatment showed a downward trend roughly proportional to the degree of blood volume reduction. This is despite the fact that in this analysis the time factor is not considered. These findings are in accord with other studies on injured civilians reported by Evans (6), Weil (44), and by McMichael (45). Hemoconcentration, therefore, cannot be considered a criterion of shock in these types of injury, rather it may be taken as a clue to the nature of the injury. When hemoconcentration occurs in traumatic shock in the ab-

"The volume of a truncated cone increases as the square of its circular measurements ( $r$ and $\mathbf{r}^{\prime}$ ). For example, the volume of the frustrum increases 31 per cent when $r$ and $r^{\prime}$ are increased by 12.5 per cent. If $r$ is increased to $k r$, and $r^{\prime}$ to $k r^{\prime}$, then $V^{\prime}=k^{2} \frac{h}{3}\left(r^{2}+r r+r^{\prime 2}\right)$. sence of dehydration and exposure, it should indicate the presence of some injury in addition to traumatic hemorrhage, the presence possibly of intra-abdominal injury.

\section{SUMMARY AND CONCLUSIONS}

Blood volume measurements on patients soon after injury reveal that in cases with clinical manifestations of shock following skeletal trauma and/ or hemorrhage, the blood volume is 30 to 40 per cent below normal. On the average, 1.5 to 2 liters of blood are required for replacement.

In cases of skeletal trauma, the reduction in blood volume is caused by the loss of whole blood at the site of the fractures and bruises. The extent of the reduction can be roughly estimated from the number and type of fractures and the extent of the tissue damage. In skeletal trauma, as in simple hemorrhage, the loss of blood is attended by hemodilution.

In burns and abdominal injuries with peritoniits, selective loss of plasma occurs at the site of injury. In burns, the loss is roughly proportional to the area of tissue damaged. The ensuing reduction in the plasma volume is attended by hemoconcentration.

The authors wish to thank Dr. Dickinson Richards and the other members of the "Shock team" for their generous cooperation which made possible the collection of sufficient data in each blood volume determination to obtain definitive answers to important theuretical questions. Grateful acknowledgment is also made to Major Octa C. Leigh who carried the burden of the preliminary work for several months until he was called to active duty in February, 1942.

\section{BIBLIOGRAPHY}

1. Keith, N. M., Med. Research Committee Special Report, No. 27, 1919.

2. Robertson, O. H., and Bock, A. V., Blood volume in wounded soldiers. I. Blood volume and related blood changes after hemorrhage. J. Exper. Med., 1919, 29, 139.

3. Robertson, O. H., and Bock, A. V., Memorandum on blood volume. Med. Research Committee Special Report, No. 25, 1918.

4. Gregersen, M. I., Traumatic Shock. Bull. New York Acad. Med., 1943, 19, 666.

5. Gregersen, M. I., et al., Unpublished reports, 19421944.

6. Evans, E. I., Hoover, M. J., James, G. W., and Alm, T., Studies on traumatic shock. I. Blood volume changes in traumatic shock. Ann. Surg., 1944, $119,64$. 
7. Warren, J. V., Stead, E. A., Jr., Merrill, A: J., and Brannon, E. S., The treatment of shock with concentrated human serum albumin. J. Clin. Invest., 1944, 23, 506.

8. Cournand, A., Riley, R. L., Bradley, S. E., Breed, E. S., Noble, R. P., Lauson, H. D., Gregersen, M. I., and Richards, D. W., Jr., Studies of the circulation in clinical shock. Surgery, 1943, 13, 964.

9. Noble, R. P., and Gregersen, M. I., Blood volume in clinical shock. I. Mixing time and disappearance rate of $\mathrm{T}-1824$ in normal subjects and in patients in shock; determination of plasma volume in man from 10-minute sample. J. Clin. Invest., 1946, 25, 158.

10. Barbour, H. G, and Hamilton, W. F., The falling drop method for determining specific gravity. J. Biol. Chem., 1926, 69, 625.

11. Neuhausen, B. S., and Rioch, D. M., The refractometric determination of serum proteins. J. Biol. Chem., 1923, 55, 353.

12. Cournand, A., Noble, R. P., Breed, E. S., Lauson, H. D., Baldwin, E. de F., Pinchot, G. B., and Richards, D. W., Jr., Clinical use of concentrated human serum albumin in shock, and comparison with whole blood and with rapid saline infusion. J. Clin. Invest., 1944, 23, 491.

13. Lauson, H. D., Bradley, S. E., and Cournand, A., The renal circulation in shock. J. Clin. Invest., 1944, 23, 381.

14. Richards, D. W., Jr., The circulation in traumatic shock in man. The Harvey Lectures, 1943-1944, p. 217. The Science Press Printing Company, Lancaster, $\mathrm{Pa}$.

15. Keith, N. M., Rowntree, L. G., and Geraghty, J. T., A method for the determination of plasma and blood volume. Arch. Int. Med., 1915, 16, 547.

16. Rowntree, L. G., and Brown, G. E., The Volume of the Blood and Plasma in Health and Disease. W. B. Saunders Company, Philadelphia, 1929.

17. Gibson, J. G., and Evans, W. A., Jr., Clinical studies of the blood volume. II. The relation of plasma and total blood volume to venous pressure, blood velocity rate, physical measurements, age and sex in ninety normal humans. J. Clin. Invest., 1937, 16, 317.

18. Stewart, J. D., and Rourke, G. M., On the measurement of extracellular fluid volume with thiocyanate and body fluid analyses in 33 normal individuals. J. Lab. and Clin. Med., 1941, 26, 1383.

19. Davis, L. J., Determination of blood volume in man with "Evans" Blue ("T-1824"). Edinburgh M. J., 1942, 49, 465.

20. Gregersen, M. I., Unpublished observations.

21. Smith, H. P., Arnold, H. R., and Whipple, G. H., Blood volume studies. VII. Comparative values of Welcker, carbon monoxide and dye methods for blood volume determinations. Am. J. Physiol., 1921, 56, 336.
22. Fåhraeus, R., The suspension stability of the blood. Physiol. Rev., 1929, 9, 241.

23. Fåhraeus, R., and Lindqvist, $T$., The viscosity of the blood in narrow capillary tubes. Am. J. Physiol., 1931, 96, 562.

24. Ebert, R. V., and Stead, E. A., Jr., Demonstration that the cell plasma ratio of blood contained in minute vessels is lower than that of venous blood. J. Clin. Invest., 1941, 20, 317.

25. Stead, E. A., Jr., and Ebert, R. V., Relationship of the plasma volume and the cell plasma ratio to the total red cell volume. Am. J. Physiol., 1941, 132, 411.

26. Hahn, P. F., Ross, J. F., Balfour, W. M., and Whipple, G. H., Red cell and plasma volumes (circulating and total) as determined by radio iron and by dye. J. Exper. Med., 1942, 75, 221.

27. Bazett, H. C., Macleod's Physiology in Modern Medicine, 9th edition. C. V. Mosby Company, St. Louis, 1941, p. 341.

28. Bazett, H. C., Sunderman, F. W., Maxfield, M. E., and Scott, J. C., Comparison of estimates of blood volume made by congo red and by carbon monoxide. Am. J. Physiol., 1940, 129, P309.

29. Gregersen, M. I., A practical method for the determination of blood volume with the dye T-1824. J. Lab. and Clin. Med., 1944, 29, 1266.

30. Hopper, J., Jr., Tabor, H., and Winkler, A. W., Simultaneous measurements of the blood volume in man and dog by means of Evans blue dye, T-1824, and by means of carbon monoxide. I. Normàl subjects. J. Clin. Invest., 1944, 23, 628.

31. Hopper, J., Jr., Winkler, A. W., and Elkinton, J. R., Simultaneous measurements of the blood volume in man and dog by means of Evans blue dye, T-1824, and by means of carbon monoxide. II. Under abnormal conditions, including secondary shock. J. Clin. Invest., 1944, 23, 636.

32. Root, W. S., Roughton, F. J. W., and Gregersen, M. I., Simultaneous measurement of blood volume with dye (T-1824) and with carbon monoxide. Proc. Am. Physiol. Soc., 1945, 4, 60.

33. Cohn, E. J., Oncley, J. L., Strong, L. E. Hughes, W. L., Jr., and Armstrong, S. H., Jr., The characterization of the protein fractions of human plasma. J. Clin. Invest., 1944, 23, 417.

34. Ebert, R. V., Stead, E. A., Jr., and Gibson, J. G., Response of normal subjects to acute blood loss with special reference to mechanism of restoration of blood volume. Arch. Int. Med., 1941, 68, 578.

35. Metcalf, W., The fate and effects of transfused serum or plasma in normal dogs. J. Clin. Invest., 1944, 23, 403.

36. Little, J. M., and Dameron, J. T., Plasma retention, urinary excretion and effect upon circulating total red cell volume of intravenous gelatin in normal dogs. Am. J. Physiol., 1943, 139, 438. 
37. McIntosh, J. F., Möller, E., and Van Slyke, D. D., Studies of urea excretion. III. The influence of body size on urea output. J. Clin. Invest., 1928, 6, 467.

38. Underhill, F. P., Carrington, G. L., Kapsinow, R., and Pack, G. T., Blood concentration changes in extensive superficial burns and their significance for systemic treatment. Arch. Int. Med., 1923, 32, 31.

39. Blalock, A., Experimental shock. Importance of local loss of fluid in production of the low blood pressure after burns. Arch. Surg., 1931, 22, 610.

40. Fine, J., and Seligman, A. M., Traumatic shock. VII. A study of the problem of "lost plasma" in hemorrhagic, tourniquet, and burn shock by use of radioactive iodo-plasma protein. J. Clin. Invest., 1944, 23, 720.

41. Cope, O., and Moore, F. D., A study of capillary permeability in experimental burns and burn shock using radioactive dyes in blood and lymph. J. Clin. Invest., 1944, 23, 241.

42. Moon, V. H., Shock, Its Dynamics, Occurrence and Management. Lea and Febiger, Philadelphia, 1942.

43. Moon, V. H., Dynamics of shock and its clinical implications. Internat. Abstr. Surg., 1944, 79, 1.

44. Weil, P. G., Shock. Canad. M. A. J., 1942, 46, 307, 417, 538.

45. McMichael, J., The practical management of wound shock. Brit. M. J., 1942, 2, 671. 